\title{
JOURNAL of PALEONTOLOGY

\section{\begin{tabular}{l|l|l} 
VOL $92 \quad$ NO 5 | 2018
\end{tabular}}

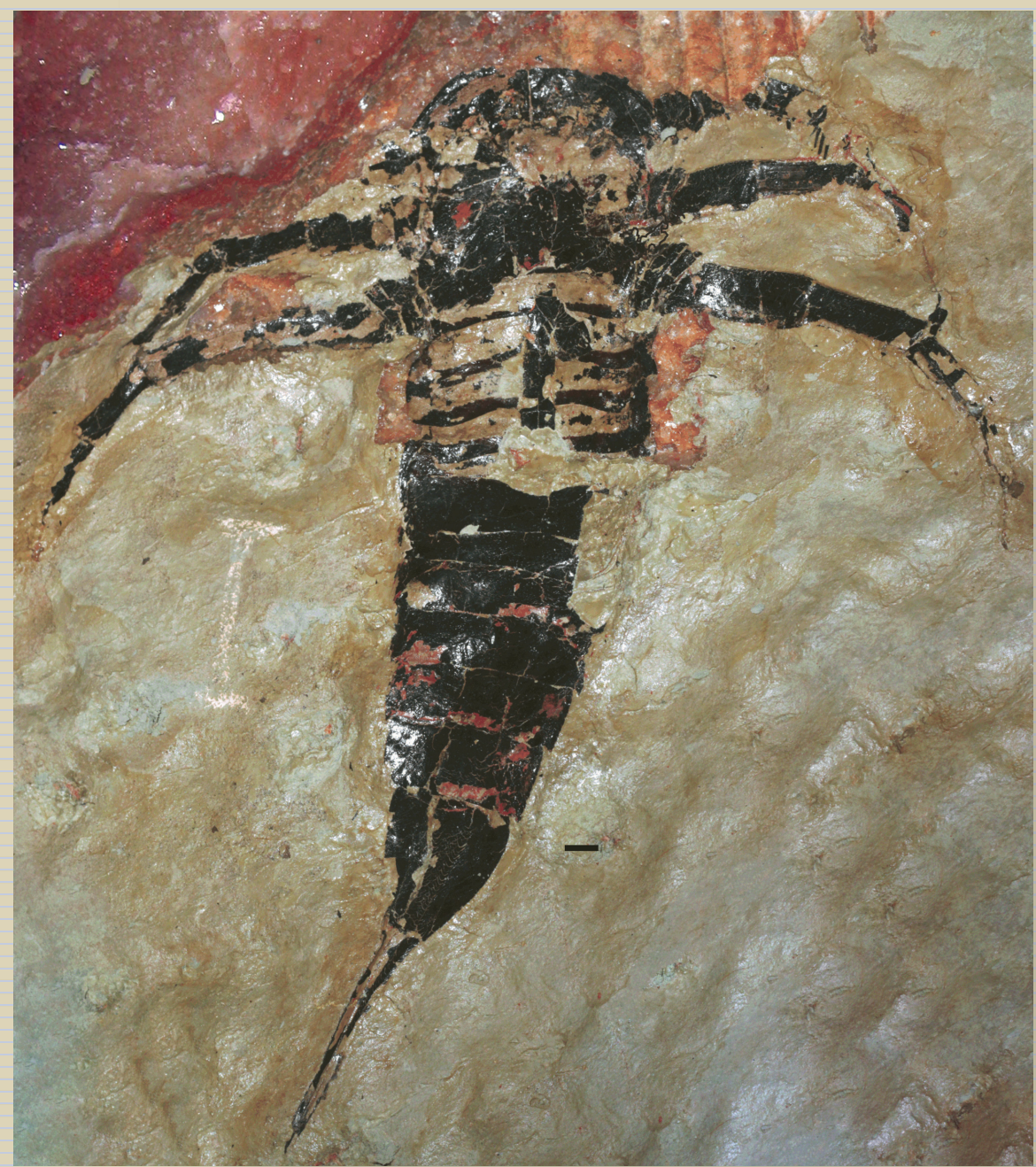

CAMBRIDGE

UNIVERSITY PRESS 


\section{OFFICERS AND EDITORS OF THE PALEONTOLOGICAL SOCIETY}

President

ARNOLD I. MILLER,

Univ. of Cincinnati

Arnold.miller@uc.edu

President-Elect

BRUCE MacFADDEN,

Florida Museum of Natural History

bmacfadd@flmnh.ufl.edu

Past President

STEVEN M. HOLLAND,

Univ. of Georgia

stratum@uga.edu

Secretary

MARGARET M. YACOBUCCI,

Bowling Green State Univ.

mmyacob@bgsu.edu

Treasurer

ALYCIA STIGALL,

Ohio University

stigall@ohio.edu

JP Editors

BRENDA R. HUNDA,

Cincinnati Museum Center

BHunda@cincymuseum.org

JISUO JIN,

Univ. of Western Ontario

jjin@uwo.ca

HANS-DIETER SUES,

Smithsonian Institution suesh@si.edu

ELLEN CURRANO,

University of Wyoming

ecurrano@uwyo.edu

JP Associate Editors

NICHOLAS BUTTERFIELD,

Cambridge Univ.

STYLIANOS CHATZIMANOLIS,

Univ. Tennessee-Chattanooga

TOM CRONIN,

USGS

WILLIAM A. DiMICHELE,

Smithsonian Institution

JAN OVE EBBESTAD

Museum of Evolution,

Uppsala University

ROBERT J. ELIAS,

Univ. of Manitoba
NADIA FRÖBISCH,

Museum für Naturkunde

PETER J. HARRIES,

North Carolina State

JOACHIM HAUG,

Ludwig Maximilian

University of Munich

MICHAEL HAUTMANN,

Univ. of Zurich

MARTIN J. HEAD, Brock Univ.

THOMAS HEGNA, Western Illinois University

SAMANTHA HOPKINS,

Univ. of Oregon

NIGEL HUGHES,

UC Riverside

DANIEL KSEPKA,

Bruce Museum

JAMES LAMSDELL,

West Virginia University

MAX LANGER,

Universidade de São Paulo

STEPHEN A. LESLIE,

James Madison Univ.

BRUCE LIEBERMAN,

Univ. of Kansas

STEVEN LoDUCA,

Eastern Michigan Univ.

RICK LUPIA,

Univer. of Oklahoma

GABRIELA MÁNGANO,

Univ. Saskatchewan

GREG McDONALD,

Bureau of Land Management

MALGORZATA

MOCZYDLOWSKA-VIDAL,

Uppsala Univ.

ALISON MURRAY,

Univ. of Alberta

PAULA NOBLE,

Univ. of Nevada

BRIAN PRATT,

University of Saskatchewan
MARY SILCOX,

Univ. of Toronto Scarborough

EDUARDO LEORRI SORIANO,

East Carolina University, Greenville

DAVID VARRICCHIO,

Montana State Univ.

STEVE WESTROP,

Oklahoma Museum

DAVID M. WORK,

Maine State Museum

PATRICK WYSE JACKSON,

Univer. of Dublin Trinity College

MARGARET M. YACOBUCCI,

Bowling Green State Univ.

SAMUEL ZAMORA,

Geological Survey of Spain

RENBIN ZHAN,

Nanjing Institute of Geology and Palaeontology,

Chinese Academy of Sciences

SHUNXIN ZHANG

Canada-Nunavut Geoscience Office

Paleobiology Senior Editor

MARK PATZKOWSKY,

Penn State Univ.

Paleobiology Co-Editors

CATHERINE BADGLEY,

Univ. of Michigan

CARLOS A. JARAMILLO,

Smithsonian Tropical Research Institute

WOLFGANG KIESSLING,

Universitat Erlangen

SHUHAI XIAO,

Virginia Polytechnic Institute

Peer Review Coordinator

JESSICA KASTIGAR,

JournalofPaleontology@cambridge.org

Paleobiology@cambridge.org

Communications Officer

TONY MARTIN

Emory Univ.

geoam@emory.edu

Program Coordinator

MATTHEW CLAPHAM,

Univ. of California, Santa Cruz mclapham@ucsc.edu
Editor, Special Publications COLIN SUMRALL

The University of Tennessee, Knoxville csumrall@utk.edu

Education/Outreach Coordinator ROWAN LOCKWOOD,

College of William \& Mary rxlock@wm.edu

Representatives At Large SUSAN KIDWELL,

University of Chicago skidwell@uchicago.edu

CAROLINE STRÖMBERG,

University of Washington

caestrom@u.washington.edu

Student Representative

KRISTOPHER M. KUSNERIK,

University of Florida

kmkusnerik@ufl.edu

Section Chairs

Cordilleran:

CARLIE PIETSCH,

carlie.pietsch@sjsu.edu

North Central:

CARRIE SCHWEITZER,

Kent State Univ.

cschweit@kent.edu

Northeastern:

JUDITH NAGEL-MYERS,

St. Lawrence Univ.

jnagel@stlaw.edu

Rocky Mountain: BROOKE LONG,

S. Dakota School of Mines \& Tech. brooke.long@mines.sdsmt.edu

South Central:

VICTORIA CHRAIBI,

Tarleton State Univ.

chraibi@tarleton.edu

Southeastern:

MICHELLE CASEY,

Murray State Univ.

mcasey5@murraystate.edu

Editor - Priscum

LEIGH FALL,

SUNY Oneonta

leigh.fall@oneonta.edu

Editor - Social Media

TARA LEPORE,

The Web Schools

taorminalepore@gmail.com

Cover illustration: Ventral surface of Soligorskopterus tchepeliensis n. gen. n. sp., holotype from the Upper Devonian salt deposits of Belarus. Plax et al., Fig. 3.1.

ISSN 0022-3360

Copyright (C) 2018 The Paleontological Society. All rights reserved. 


\section{SUBSCRIPTION INFORMATION}

The Journal of Paleontology [ISSN 0022-3360] is published bimonthly (January, March, May, July, September, and November) by Cambridge University Press for the Paleontological Society. Members of the Paleontological Society automatically receive electronic subscriptions to the

Journal of Paleontology and Paleobiology as a benefit of membership. Institutional subscriptions can be purchased direct from Cambridge University Press or through any major subscription agent. Print-only, online-only, and bundled print and online prices are all available, and subscription prices are tiered according to institution type and size.

Please contact Cambridge University Press for further details:

For customers in North America

Email: subscriptions_newyork@cambridge.org;

Phone: (800) 872-7423, option 4

For customers outside of North America

Email: journals@cambridge.org;

Phone: +44 (0)1223-32-6070; Fax: +44 (0)1223-32-5150

Downloads of individual articles are available on https://www.cambridge.org/core/journals/journal-of-paleontology.

Reprints of individual articles may be ordered. For information on reprints, please contact Cambridge University Press.

Archives of previous issues are available on https://www.cambridge.org/core/journals/journal-of-paleontology.

Permissions All rights reserved. Permissions and reproduction policies, request forms, and contacts are available at: http://www.cambridge.org/about-us/ rights-permissions/

ADVERTISING

To advertise in the journal please contact M. J. Mrvica Associates, 2 West Taunton Avenue, Berlin, NJ 08009; Phone: 856-768-9360; Fax: 856-753-0064; Email: mjmrvica@mrvica.com

\section{ABSTRACTING AND INDEXING}

Abstracting and indexing information for the Journal of Paleontology is available at: https://www.cambridge.org/core/journals/journal-ofpaleontology/information/abstracting-and-indexing.

\section{POSTAL INFORMATION}

Periodicals postage rate paid at New York, NY, and at additional mailing offices. POSTMASTER: Send address changes in the USA, Canada, and Mexico to: Journal of Paleontology, Cambridge University Press, Journals Fulfillment Department, One Liberty Plaza, 20th Floor, New York, NY 10006. Send address changes elsewhere to the Journal of Paleontology, Cambridge University Press, Journals Fulfillment Department, UPH, Shaftesbury Road, Cambridge CB2 8BS, England.

Copyright (C) 2018 The Paleontological Society. All rights reserved.

Printed in the United States of America 
https://doi.org/10.1017/jpa.2018.63 Published online by Cambridge University Press 